\title{
The location of Japanese investments in China: agglomeration effects, Keiretsu, and firm heterogeneity
}

Citation for published version (APA):

Belderbos, R. A., \& Carree, M. A. (2000). The location of Japanese investments in China: agglomeration effects, Keiretsu, and firm heterogeneity. NIBOR, Netherlands Institute of Business Organization and Strategy Research. NIBOR Research Memorandum No. 02 https://doi.org/10.26481/umanib.2000002

Document status and date:

Published: 01/01/2000

DOI:

10.26481/umanib.2000002

Document Version:

Publisher's PDF, also known as Version of record

\section{Please check the document version of this publication:}

- A submitted manuscript is the version of the article upon submission and before peer-review. There can be important differences between the submitted version and the official published version of record. People interested in the research are advised to contact the author for the final version of the publication, or visit the DOI to the publisher's website.

- The final author version and the galley proof are versions of the publication after peer review.

- The final published version features the final layout of the paper including the volume, issue and page numbers.

Link to publication

\footnotetext{
General rights rights.

- You may freely distribute the URL identifying the publication in the public portal. please follow below link for the End User Agreement:

www.umlib.nl/taverne-license

Take down policy

If you believe that this document breaches copyright please contact us at:

repository@maastrichtuniversity.nl

providing details and we will investigate your claim.
}

Copyright and moral rights for the publications made accessible in the public portal are retained by the authors and/or other copyright owners and it is a condition of accessing publications that users recognise and abide by the legal requirements associated with these

- Users may download and print one copy of any publication from the public portal for the purpose of private study or research.

- You may not further distribute the material or use it for any profit-making activity or commercial gain

If the publication is distributed under the terms of Article $25 \mathrm{fa}$ of the Dutch Copyright Act, indicated by the "Taverne" license above, 


\title{
The Location of Japanese Investments in China: Agglomeration Effects, Keiretsu, and Firm Heterogeneity*
}

\section{NIBOR Research Memorandum RM/00/02}

\author{
René Belderbos and Martin Carree
}

Maastricht University

Correspondence to:

Department of Management Science

Faculty of Economics and Business Administration

Maastricht University

PO BOX 616, 6200 MD Maastricht, The Netherlands

Fax: +31433884877

Phone: + 31433883445 ; + 31433883763

Email: r.belderbos@mw.unimaas.nl; m.carree@mw.unimaas.nl

* The authors' research is funded by their respective fellowships from the Royal Netherlands Academy of Arts and Sciences (KNAW). They are indebted to Ding Xianping and John Ries for generous provision of Chinese statistics. The paper benefited from helpful comments of participants at seminars at Maastricht University and the Catholic University of Leuven. 


\title{
The Location of Japanese Investments in China: Agglomeration Effects, Keiretsu, and Firm Heterogeneity
}

\begin{abstract}
Conditional logit analysis of the locational choice by Japanese electronics firms in China's regions and provinces during 1990-1995 confirms a major impact of general industry, Japanese, and keiretsu-specific agglomeration benefits. Further analysis reveals a substantial aggregation bias due to the presence of firm heterogeneities in terms of investor size and market orientation of manufacturing investments. Small and medium sized enterprises are more sensitive to distance from Japan and Japanese agglomeration, but less sensitive to the presence of incentive zones. Export oriented plants are more responsive than local market oriented plants to keiretsu agglomeration and seaports but less responsive to regional demand.
\end{abstract}

Keywords: $\quad$ Direct Foreign Investment, Locational Choice, Multinational Firms

JEL Codes: F23, R30 


\section{INTRODUCTION}

There is now a substantial body of literature on the location decisions for multinational firms' overseas manufacturing investments. Studies have examined what characteristics attract foreign investment to US states, to countries and regions within the European Union, and to regions and cities within China. ${ }^{1}$ A common finding in recent studies is that regions with a relatively higher existing stock of foreign investment are more likely to attract further investments, after controlling for various other regional characteristics affecting locational choice (e.g. Wheeler and Mody 1992, Head et al. 1995, Head and Ries 1996, O'Huallachain and Reid 1997, Mayer and Muchielli 1998). This confirms the importance of positive agglomeration externalities conferred by proximity to clusters of other foreign investors, which may owe to information externalities concerning the operating environment, greater availability of specialized inputs and labor, and technology spillovers (c.f. Head et al. 1999, Krugman 1991). Studies of Japanese firms' investment location decisions in the US and Europe have found evidence that such agglomeration benefits are greater in the case proximate manufacturing plants are operated by other Japanese firms and, in case of automotive investments, Japanese firms belonging to the same vertical keiretsu (Head and Ries 1995, Smith and Florida 1994, Mayer and Muchielli 1998, O'Huallachain and Reid 1997). These greater benefits of clustering can be attributed to easier information sharing among Japanese firms (e.g. Branstetter 2000), national preferences for amenities such as schools and restaurants, greater advantages of proximity due to the use of just in time delivery and inventory control systems (Reid 1994), and the use of specialized components and intermediates of which the specifications are developed within long-term supplier-assembler relationships in Japan (Hackett and Srinivasan 1998, Sako 1992, Asanuma 1989).

An issue that has received only sparse attention in the literature is the potential heterogeneity in the responses of investors to locational determinants, depending on the characteristics of the investing firm and the plant. If firm and plant heterogeneity have a non-random effect, estimation results suffer from aggregation bias. A few studies have investigated aspects of firm heterogeneity. In an early 
study, Schmenner et al. (1987) examine interaction effects between investor preferences and US state characteristics. Friedman et al. (1996) find significant differences in locational choice between new ventures and acquisitions by foreign firms in the United States. Head et al. (1995) do not find strong across-industry heterogeneity in Japanese investment location decisions in the US. In a recent study by Shaver and Flyer (2000) it is argued that firms are heterogeneous in the benefits they receive and the contributions they make to agglomeration economies. Firms with the most innovative technologies and training programs contribute relatively more to spillovers within industry clusters and therefore receive fewer net benefits. Evidence is found that locational decisions by such firms are indeed less influenced by the presence of industry agglomerations in US states. ${ }^{2}$

In this paper, we examine two sources of heterogeneity that merit further exploration: differences in locational choices between small and medium size enterprises (SMEs) and larger firms, and differences in locational choices between export oriented and local market oriented plants. We examine the effects of these two sources of firm and plant heterogeneity in the context of Japanese electronics firms' new plant establishments in China's regions and provinces in the first half of the 1990s. Small and medium size enterprises (SMEs) may react more strongly to agglomeration externalities due to the relatively greater risks associated with foreign investment, relatively greater cost associated with gathering information on alternative locations and negotiating with local authorities, and relatively greater benefits from spillovers. A feature of inward investment in various developing and newly industrializing countries is that they attract both (import substituting) investments serving the local market and export oriented investments. Depending on market orientation, plants are likely to manufacture different varieties of products and to require different (qualities of) inputs. Export oriented plants are likely to be more responsive to the quality of the international trade infrastructure, while local market oriented plants are more sensitive to the proximity to concentrations of local demand.

We use a conditional logit model to analyze the influence of regional characteristics on the establishment decisions of 229 Japanese plants in the broadly defined electronics industry in 29 
Chinese regions and provinces during 1990-1995. China is an interesting country to investigate given the large share of overseas investment flows to developing countries that it receives and the importance of foreign direct investment inflows to its economy. ${ }^{3}$ The restriction to the electronics industry, although limiting the scope for generalization of results, has a number of advantages. It allows us to use a detailed data source on Japanese investments that contains information on the total population of Japanese plants and a range of characteristics such as export orientation. ${ }^{4}$ This population includes a relatively large number of investments by SMEs and specialized suppliers to the electronics industry. It enables us to examine the effects of firm heterogeneity and to accurately measure within-industry agglomeration effects related to the proximity of relevant suppliers.

Our results show robust positive effects of Japanese plant agglomeration in addition to general electronics industry agglomeration. In addition, we show that keiretsu plant agglomeration effects are not a feature solely present in the automotive industry in the United States but extend to the electronics industry and developing countries, once we take into account differences in locational choice between the leading 'core' firms and the member firms of the group. The results confirm that the impact of agglomeration effects and a number of other regional characteristics differ depending on market orientation and firm size. In the next section we develop hypotheses concerning firm heterogeneity and its impact on locational choice. Section three describes the model and dataset. Section four presents the results and section five concludes.

\section{AGGLOMERATION EFFECTS, FIRM HETEROGENEITY, AND LOCATIONAL CHOICE}

We build on the established literature on location decisions for foreign investment to determine the regional characteristics that are to affect Japanese firms' locational choices in China. In the last paragraphs of the section we develop hypotheses concerning the differences in locational choice depending on firm size and market orientation. 


\section{Agglomeration Effects and Regional Characteristics}

We follow Head et al. (1999) by including into the empirical model three different measures of agglomeration in addition to a set of regional characteristics. Industry agglomeration is a count of establishments in the electronics industry in the region taken from China Industrial Statistics. If our empirical model duly controls for other regional characteristics affecting investment location choice, this count measures the effect of positive externalities associated with the proximate location of similar manufacturing activities. Such externalities may stem from various sources, but in case of foreign investment in China, the most powerful influence is expected to come from greater availability and variety in parts and components. Component sourcing is an important consideration for foreign manufacturing firms in China because Chinese authorities often include minimum local content requirements in contractual arrangements with foreign investors and since foreign firms are often required to balance foreign currency transactions, indirectly restricting component and material import (Head and Ries 1996; Belderbos et al. 2000). Head and Ries (1996) develop a model in which the presence of foreign firms induces local manufacturers to incur a fixed cost in adapting process and products to the specific needs of the foreign sector. This increases the variety of intermediates available and the productivity of foreign manufacturers, setting in motion an agglomeration process. Similarly, Venables (1996) finds that vertical linkages can induce clustering of suppliers and assemblers in specific locations.

We also include an additional Japanese agglomeration variable: the count of existing Japanese electronics establishments in the region. We calculated this count from Asia Shinshutsu Denshi Meika (published by Denshi Keizai Kenkyujo in Tokyo): an encompassing source of Japanese electronics manufacturing affiliates in Asia. If this count has a positive impact it implies that agglomeration benefits are stronger in case the proximate manufacturers are Japanese owned. There are several reasons to expect such a larger impact. Japanese firms may derive useful information on how to operate manufacturing plants in a region from the experience of other Japanese firms. Firms will find 
it is easy to communicate with fellow nationals and they are likely to have frequent contacts and opportunities for information exchange in Japan, e.g. through joint membership of industry associations (e.g. Sako 1992). Second, Japanese firms share certain operational and management features, such as a strong reliance on quality control and just in time delivery systems, due to which greater externalities are created in case of Japanese plant agglomeration. Just in time delivery require close spatial concentration of manufacturing plants and strict production flow control by suppliers, which is easier achieved by Japanese suppliers experienced with the system (e.g. Reid 1994). Quality control imposes equally strong demands on locally established suppliers, which can be satisfied more easily by Japanese firms with experience in total quality management.

The third agglomeration variables is keiretsu agglomeration. It is defined as the number of existing establishments in the region owned by the 'core' firm or other member firms of the same vertical keiretsu. We determined Keiretsu membership based on the listings in Toyo Keizai's Nihon Kigyou Guruppu, Nihon Keizai Shimbun's Kigyou Keiretsu Souran, and the directory Denshi Mekah Risuto published by Denshi Keizai Kenkyujo. We considered member firms in which the 'core' firm had an equity stake and for which the 'core' firm or other member firms in the group were listed as major suppliers or customers. We expect an additional impact of plant agglomerations of keiretsu 'core' and member firms. First, vertical keiretsu are characterized by intensive inter-firm flows of information and the core firm may give active assistance to member firms in the process of overseas relocation. Second, suppliers within vertical keiretsu often manufacture specialized components to the design specification of the core firm, and such supplier relationships are often replicated abroad. Economies of scale in the production of the component can be reaped with larger keiretsu activities in the location. The electronics industry differs from the automotive industry in that it is characterized by a more diverse pattern of specialization between 'core' and member firms. Core firms generally manufacture a range of final goods but also manufacture various key components (such as specialized integrated circuits), while member firms can also be specialized in the production of final goods. For example, Fujitsu manufactures integrated circuits and other components and is a supplier to car radio 
manufacturer and member firm Fujitsu Ten. Hitachi has a similar relationship with audio manufacturer Nippon Columbia (which markets under the Denon brand). ${ }^{5}$

The literature to date has found evidence of keiretsu agglomeration only for the automotive industry (Smith and Florida 1995, Head et al. 1995, O'Huallachain and Reid 1997). Yet there is ample evidence that keiretsu interaction in foreign investment is an important feature of the Japanese electronics industry as well. Belderbos et al. (2000) find that electronics keiretsu affiliates in Asia have higher than average local procurement ratios in countries with a stronger presence of Japanese electronics producers, suggesting that existing keiretsu supplier linkages are replicated abroad. Belderbos and Sleuwaegen (1996) find that the size of the manufacturing network of 'core' firms abroad increases the probability that member firms follow the 'core' firm in setting up a manufacturing plant abroad. Pugel and Kimura (1996) find evidence of such 'follow the leader' investment by Japanese firms in the US for both the electronics and automotive industries. The observed 'follow the leader' pattern suggests a differential pattern in the investment and location decision by keiretsu 'core' firms and keiretsu member firms that has not been explored in location studies. If the 'core' firm takes the lead, it will explore alternative locations, negotiate with local governments and decide on the most profitable site. It can do so in the expectation that a number of member firms in the group is likely to follow it to the chosen location. Investment by the 'core' firm makes the location more attractive and the 'core' firm moreover will be able to exert a degree of influence on the foreign investment decisions of member firms. ${ }^{6}$ This suggests that member firms respond to local agglomerations of keiretsu manufacturing activity but that this effect is much less strong for the 'core' firms. We test this hypothesis by estimating the effect of keiretsu agglomeration separately for member firms and for core firms.

We control for other regional characteristics that have been found to affect investment locations in earlier empirical work. We control for differences in the economic size of the regions by including GDP of the region. The larger the economic size of a region, the more likely that it will receive foreign investments (e.g. Wheeler and Mody 1992, Coughlin and Segev 2000, p.13). ${ }^{7}$ Inclusion of 
GDP ensures that the coefficients of the agglomeration variables are not biased upwards because the agglomeration counts are correlated with the region's size. In addition, we include GDP per capita of the region as a measure of potential demand for foreign investors' products (e.g. Chen and Kwan 2000)

We control for the cost of labor by including the average wage level of industrial workers in the region, taken from China Statistical Yearbook. In previous empirical studies, mixed results have been found for wage effects, even when allowing for differences in labor productivity and labor skill. In case of electronics investments in China, we expect the wage level to discourage investments. Most electronics assembly operations are labor intensive but not highly skill intensive and a major motivation to invest in the Chinese electronics industry is to benefit from low cost of relatively unskilled labor. Other Asian countries such as Singapore are chosen for assembly operations that necessitate more engineering skills and qualified labor inputs (c.f. Belderbos and Sleuwaegen 1996).

A common finding in empirical studies on foreign investment location is that the cost and quality of infrastructure influences locational choice. A well developed transportation infrastructure reduces the costs of importing components and machinery and exporting or distributing output. A good communication infrastructure facilitates and reduces the cost of communication between the Chinese manufacturing operations and headquarters and other affiliates, lowering the cost of effective management control of affiliates. We include the dummy variable seaport, which takes the value one if a major port city is located in the region. If this is the case, import and export of materials, components, and final goods, a major share of which is shipped by sea, is more cost effective. We also include a measure of the quality of telecommunication infrastructure: the number of longdistance telephone lines per capita. Greater availability of long distance telecommunication services implies easier use of modern communication technologies at lower cost (c.f. Head and Ries 1996).

A number of studies have found a preference by foreign investors to locate in the region nearest to their home country. For instance, Japanese firms in the US show a preference for the Westcoast and 
tend to avoid the Southeast (Caves 1996, p.54, Head et al. 1995). Caves (1996, p.58) argues that location choice is affected by differences in the costs of gathering information on potential sites, and that this often favors proximate sites (both in terms of geographic and cultural distance). In addition, the costs of controlling and managing overseas affiliates from headquarters in Japan will be lower for regions that are closer to the home country, as communication and transport cost as well as travel costs (for managers and technicians) increase with distance. We include distance from Japan as an explanatory variable and expect a negative sign. Distance from Japan is measured as the number of flight hours from Tokyo to the region's main airport.

We also control for financial and other incentives granted to foreign investors in designated economic zones. Previous studies have found an important impact of early established zones with the broadest range of incentives: the four Special Economic Zones (SEZs) established in 1980, and the 14 Opening Coastal Cities (OCCs) designated in 1984 (e.g. Chen and Kwan 2000, Coughlin and Segev 2000). Instead of using a simple zone count per region, we include the variable SEZ \& OCC share, which measures the relative importance of the incentive zones for the regions. SEZ \& OCC share is calculated as the share in the region's GDP (in 1992) accounted for by SEZs and OCCs. ${ }^{8}$ This variable should give a good indication of whether incentive zones are a major distinctive feature of the region.

\section{Small and Medium Size Firms and Locational Choice}

There are a number of theoretical arguments why small and medium sized enterprises (SMEs) are likely to show locational preferences that differ from those of larger firms. Our data on Japanese electronics investments in China allow us to investigate these differences since about one third of the plants are owned by SMEs (parent firms with less than 500 employees). SMEs are facing the same fixed information cost associated with site selection, but cannot spread these costs over large operations. It is relative more cost effective for them to distill information from observed locational choices of other firms rather than investigating a large number of alternative sites. Hence, SMEs are more likely to follow the investment behavior of previous investors to sites with Japanese 
agglomeration. Second, smaller firms' success or failure of relatively risky foreign investment projects are more likely to affect their overall chances of survival. SMEs are therefore likely to avoid high risk locational choice strategies. ${ }^{9}$ An incremental approach, choosing sites that are closer to headquarters or close to similar firms' successful manufacturing plants, is likely to be chosen. Third, SMEs, due to their size, contribute relatively less to local agglomeration externalities, while they benefit as much as large firms. Large firms are more likely to take into account that their contribution to externalities can have a negative effect on their performance by benefiting rival firms (Shaver and Flyer 2000). For instance, an in-house training program increasing specific skill levels of local workers may be less effective if rival firms can hire away these workers after they completed their training. These negative externalities that could be associated with locating near agglomerations of investors play a much smaller role for SMEs.

The hypothesis follows that the locational choice of SMEs is more responsive to Japanese agglomeration than that of large firms: we include the cross effect of an SME dummy with Japanese agglomeration and expect a positive sign. The second argument suggests that SMEs will have a greater preference than larger firms for sites that are closer to headquarters in Japan. In addition, sites close to headquarters have the advantage of reducing travel costs and travel time for managers and technicians, costs that weigh more heavily for SMEs with limited management and engineering resources. We include the cross effect of the SME dummy and distance from Japan and expect a negative sign. Finally, we expect small firms to be less likely to benefit from the SEZ- and OCCincentives for foreign investors. SMEs will be less able to extract maximum benefits given the costly and time-consuming negotiations with Chinese authorities. The authorities are more likely to grant substantial incentives to large firms with greater bargaining power. UNCTAD (1998, p. 43) reports that SMEs investing in Asian developing countries find it difficult to get access to existing regional investment incentive schemes and are less able to benefit from such incentives. We incorporate a third cross term of the SME dummy and SEZs and OCCs share and expect a negative sign. 


\section{Market Orientation and Locational Choice}

A feature of foreign manufacturing operations in China established since the early 1990s is that there are important differences in market orientation between plants. ${ }^{10}$ Within the population of Japanese electronics plants, 25 percent have a 1994-1995 local sales ratio of 10 percent or less, while almost half of the plants record a local sales ratio of more than 90 percent. Belderbos et al. (2000) find significant differences in materials and component procurement behavior between Japanese electronics affiliates in China and ASEAN countries depending on such differences in market orientation. Export intensive affiliates exhibit lower local content ratios than local market oriented affiliates, which they attribute to differences in product varieties produced for export and local markets. In comparison with products destined for the local (Chinese) market, export products are more likely to face stricter quality standards and to require higher quality but costlier (sub)components typically manufactured by long-standing Japanese suppliers. Procurement of high quality (sub)components such as specific integrated circuits, circuit boards, or cathode ray tubes, is particularly important in case these components involve proprietary technology jointly developed between suppliers and assemblers within vertical keiretsu (Hackett and Srinivasan 1998). Hence, we expect that in case of export orientation, proximity to Japanese (or keiretsu) electronics plants provides relatively greater benefits while proximity to general industry agglomeration is less important. We include the cross effects of local sales orientation with industry agglomeration, Japanese agglomeration, and keiretsu agglomeration and expect a positive sign for the first and negative signs for the latter two.

We also expect different responses to regional characteristics depending on market orientation. Firms selling output locally benefit more from local concentration of industrial and consumer demand. We include the cross effect of local sales orientation and GDP per capita and expect a positive sign. Another, relatively straightforward, difference between export oriented and local market oriented plants is that the former use the international trade infrastructure more intensively. Hence we hypothesize that the indicator of infrastructure that is of direct importance to international trade, the 
availability of a seaport, is of less relevance to local market oriented plants. We include the cross effect of local sales orientation and seaport and expect a negative sign.

\section{MODEL AND DATA}

We use a conditional logit model to analyze the effect of regional characteristics on Japanese firms' location choice (McFadden 1984). Since the conditional logit model has been widely used in previous empirical studies of location choice, we do not discuss its properties here in detail. It suffices to remark that the model can be derived from profit maximizing firm behavior under appropriate assumptions concerning the stochastic term in the profit function. ${ }^{11}$ The probability that a certain investor $j$ chooses a region $s$ to start up a plant $q$ depends on four types of characteristics. Type I are regional characteristics $\left(R_{s}\right)$ that have equal effects across firms and plants. Type II are regional characteristics $\left(R_{s}^{j}\right)$ that have a differential impact depending on keiretsu membership status. Type III are regional characteristics $\left(R_{s} Y_{j}\right)$ that differ in their impact depending on the size of the parent firm (the SME dummy $\left.Y_{j}\right)$. Type IV are regional characteristics $\left(R_{s} Z_{q}\right)$ that have a differential impact depending on the sales orientation of the plant (local sales ratio $Z_{q}$ ). The probability that investor $j$ chooses a region $s$ to set up plant $q$ is then expressed as:

$$
P_{s q}^{j}=\frac{\exp \left(\sum_{i} \alpha_{i} R_{s i}+\beta_{i} R_{s i}^{j}+\gamma_{i} R_{s i} Y_{j}+\delta_{i} R_{s i} Z_{q}\right)}{\sum_{s} \exp \left(\sum_{i} \alpha_{i} R_{s i}+\beta_{i} R_{s i}^{j}+\gamma_{i} R_{s i} Y_{j}+\delta_{i} R_{s i} Z_{q}\right)}
$$

where $i$ is a variable index. Since we are interested in the differential impact of regional characteristics on locational choice, we include an elaborate set of regional and agglomeration characteristics rather than fixed regional effects. ${ }^{12}$ The assumption of independent errors may be violated in case neighboring regions are closer substitutes than more distant ones. This potential bias 
could be reduced by including adjacent state characteristics (e.g. Head et al. 1995). However, Coughlin and Segev (2000) test for such spatial dependency in case of inward investment in China and conclude that this has no significant effect on the estimated coefficients of regional characteristics. ${ }^{13}$ Given these findings and our specific focus on the interaction between regional characteristics and firm and plant characteristics, we decided against inclusion of adjacent regional effects.

Our dataset consists of the population of 229 Japanese entries into China's electronics industry between 1990 and early 1995. The detailed and complete lists of manufacturing affiliates are compiled and published as Asia Shinshutsu Denshi Meika (Electronics Firms in Asia) by Denshi Keizai Kenkyujo in Tokyo. The 229 plants include 52 plants set up by keiretsu 'core' firms and 36 plants set up by member firms. Nine keiretsu had investments by both 'core' and member firms in China with the largest groups being Matsushita, Sanyo, Toshiba, Fujitsu, and NEC. The choice set includes 29 different regions: all Chinese provinces, autonomous regions, and centrally administered municipalities with the exception of Tibet, for which no reliable information is available. The distribution of investments over regions is skewed. Only 13 provinces received investments with the most attractive regions, Guangdong and Shanghai, receiving slightly less than half of the total. This could indicate that non-investment regions would not be equal substitutes for regions that did attract investment, violating the Independence of Irrelevant Alternatives (IIA) property of the conditional logit model. We therefore report the results of a model in which the zero-choice regions are excluded and report the results of the IIA test.

A description and summary statistics of the explanatory variables are provided in Table 1. All regional characteristics, including agglomeration variables, are lagged by one year. The variables that vary with the size of the region (GDP and agglomeration) are taken in natural logarithms. In case of agglomeration variables, the logarithm is taken after adding the value 1 , which is consistent with the premise that prospective investors take into account the addition of their own plant to agglomeration 
effects in a region. Table 1 shows that 32 percent of the plants were owned by SMEs, while the local sales ratio of the Japanese plants on average reached 61 percent.

\section{EMPIRICAL RESULTS}

In this section we discuss the conditional logit estimates for the models with and without heterogeneity in firms' responses to regional characteristics. The estimation results are given in Table 2. We consider four different models. The first, basic, model does not allow for firm and plant heterogeneities apart from keiretsu membership. The second model includes the same explanatory variables as the basic model but excludes regions that did not attract any investments during the 19901995 period. In the third model we allow for firm heterogeneity with respect to firm size. The fourth model includes heterogeneity with respect to the local sales ratio of the plants.

In the basic model, overall industry agglomeration and Japanese agglomeration have a significantly positive effect on plant location choice. The coefficient of 0.909 for industry agglomeration implies that on average, if a region increases its number of establishments by 10 percent, it has a 8.8 percent higher probability that an investor chooses to locate in it. ${ }^{14}$ The coefficient of 0.471 for Japanese agglomeration implies that the effect of proximate Japanese-owned plants is about 1.5 times as large as the effect of other plants. The significantly positive coefficient for keiretsu agglomeration in case of investments by member firms suggests that in case the proximate plants are operated by firms within the same keiretsu, this impact is almost 2.5 times as large. On the other hand, this additional effect is absent in case of investments by the leading 'core' firm of the keiretsu, as the coefficient of keiretsu agglomeration for 'core' firms is insignificant. These results are consistent with the view that 'core' firms take a leading independent role in searching for appropriate locations, while member firms are most likely to follow the 'core' firm's lead. 
Among other regional characteristics, regional GDP as a measure of the economic size of the region has the expected positive effect. The telecommunications infrastructure variable (long-distance telephone lines per capita) has the wrong sign but is not significantly different from zero. On the other hand, GDP per capita has a strong positive effect on plant location. The insignificant effect of telephone lines per capita may be related to the high correlation (0.92) with GDP per capita (see the appendix). ${ }^{15}$ GDP per capita may have explanatory power both as a proxy for regional purchasing power and as a proxy for the level of regional economic development. The latter will be closely correlated with the quality of various infrastructural facilities. The effect of regional wage levels is negative and strongly significant, suggesting that Japanese electronics firms are seeking to reduce labor cost in China. The distance of the region from Japan and the availability of seaports have no significant impact in the basic model, but investment incentives in Special Economic Zones and Open Coastal Cities do appear to have a positive and significant impact.

Model 2 tests the robustness of the results of the basic model to the exclusion of regions that did not attract investments. Apart from somewhat lower coefficients for industry agglomeration and wage level, the restricted model does not show substantially different results. This is confirmed by the Hausman test statistic (Hausman and McFadden 1984) on the difference between the estimates for the full sample and the sample excluding zero investments regions. The statistic has a value of 20.17 (16 degrees of freedom) against a critical value of 26.30 at the 5 percent significance level and suggests that the basic model does not violate the Independence of Irrelevant Alternatives condition.

The results of Model 3 show that there are systematic differences in locational choices between SMEs and larger firms. As hypothesized, the additional impact of the Japanese agglomeration variable is substantially larger (0.510 and significant) for SMEs than for larger investors. In addition, the distance from Japan variable is negative and significant for SMEs, but insignificant for other firms, confirming that SMEs are more likely to choose locations close to their headquarters. The results also suggest that SMEs are less likely to extract substantial investment incentives from Chinese authorities in SEZs and OCCs, as the effect of such special incentive zones on locational choice is significantly smaller for 
SMEs compared with larger firms (the cross effect of SEZ and OCC share and the SME dummy is $0.011)$.

The results of the fourth model allowing for plant heterogeneity with respect to sales orientation provide partial support for our hypotheses. Although all the cross terms of local sales ratio and the agglomeration variables have the predicted sign, only the cross term with keiretsu agglomeration for member firms is significant. The estimated coefficients for keiretsu agglomeration imply only a small positive effect in case of a local market orientation of member firms, and a very large agglomeration effect (3.015) in case keiretsu plants concentrate on exports. This suggests that major agglomeration benefits are derived in export intensive clusters of keiretsu affiliates, which may be due to the importance of high quality (sub)components and materials developed within the keiretsu intra-group in case of export to developed markets. Heterogeneity in terms of market orientation also has major consequences for the impact of demand factors and trade infrastructure. The positive and significant (at the 10 percent level) cross effect of GDP per capita and local sales ratio shows that local market oriented plants, as expected, are more sensitive to concentrations in industrial and consumer demand. ${ }^{16}$ The positive and significant effect of seaport combined with the negative and significant effect of the cross term of seaport and local sales ratio confirms that access to seaports is only a relevant factor in plant location for export oriented plants. The insignificant effect of seaport in the basic model is the result of unwarranted aggregation of local market and export oriented plants.

Allowing for the two types of heterogeneity leads to a statistically improved model fit. The likelihood ratio test for model 3 compared with the basic model is 12.49 (three degrees of freedom) and is significant at the 1 percent level. Similarly the inclusion of the cross effects with sales orientation substantially improves the fit of the model. The loglikelihood ratio test statistic comparing model 4 with a same-sample basic model is 30.33 (six degrees of freedom) and significant at the 1 percent level. The two types of heterogeneity moreover have largely independent impacts and independently improve the model of locational choice. This can be seen from the low correlation coefficient $(-0.19)$ between the SME dummy and the local sales ratio and from a significant likelihood ratio test 
comparing a model with all cross-terms included with the sales orientation heterogeneity model (a test-statistic of 7.69 with 3 degrees of freedom, significant at the 10 percent level).

\section{CONCLUDING REMARKS}

Conditional logit analysis of the locational choice of Japanese electronics manufacturers in China's regions and provinces shows a major impact of agglomeration effects, after controlling for regional characteristics such as economic size, demand potential, wage levels, infrastructure, distance from Japan and investment incentives. Using detailed data on the population of Japanese electronics affiliates in 1990-1995, we find that the probability that a firm chooses a region is positively affected by the presence of existing electronics manufacturing establishments. This positive impact is substantially larger if existing plants are Japanese owned and even more so if plants are owned by other firms in the prospective investor's vertical keiretsu. These results confirm that the presence of ownership- and keiretsu-specific agglomeration benefits is not limited to the case of Japanese automobile industry investments in the United States (Head et al. 1995) but extend to the electronics manufacturing industry and investments in a developing country. The positive impact on locational choice of keiretsu plant agglomerations does not apply to the 'core' firms of the group, consistent with the view that 'core' firms take the lead in seeking attractive locations while member firms of the group 'follow the leader' (e.g. Smith and Florida 1994, Belderbos and Sleuwaegen 1996).

Our analysis also provides evidence of significant heterogeneities in investors' responses to agglomeration benefits and regional characteristics. SMEs are attracted more strongly to Japanese plant agglomerations, are more likely to locate in regions closer to Japan, and are less sensitive to the availability of investment incentives compared to larger firms. Small size implies a relatively greater burden of the costs of travel, transport and information gathering, a relatively greater impact of the risk of failure of foreign investment projects, relatively greater benefits from agglomeration externalities, and smaller bargaining power in contractual and subsidy negotiations with local 
authorities. A second, largely independent, form of heterogeneity relates to the market orientation of Japanese plants. Plants that focus on production for export are more likely to be set up in regions with seaports and less likely to locate near concentrations of regional consumer and industrial demand. Moreover, keiretsu agglomeration plays a much larger role in case of export oriented plants, suggesting that these plants produce varieties of electronics products for which high quality and proprietary components developed and produced within the keiretsu are major inputs.

The results indicate that locational choice models that do not allow for firm and plant heterogeneities are likely to suffer from aggregation bias. Although our analysis of Japanese electronics establishments in China does not allow for broad generalizations, there is a priori no reason why the differences in investment behavior between SMEs and larger firms should not apply to investments in other industries and countries or foreign investments by firms based in other countries than Japan. ${ }^{17}$ Similarly, differences in locational choices between export oriented and domestic market oriented plants is likely to be a feature of other large developing countries with specific export oriented growth policies. On the other hand, the particular strength of agglomeration effects linked to the quality and variety of local inputs may be specific to assembly industries such as automobile and electronics manufacturing which require a large variety in component supplies. Further empirical work on locational choice should also establish whether ownership-specific agglomeration benefits are a feature reserved for Japanese foreign investment or whether they are relevant for locational choices by investors based in other countries.

\section{REFERENCES}

Asanuma, Banri, 1989, Manufacturer-Supplier Relationships in Japan and the Concept of RelationSpecific Skill, Journal of the Japanese and International Economies, 3, 1-30. 
Belderbos, René A, Giovanni Capannelli and Kyoji Fukao, 2000, Local Procurement by Japanese Electronics Firms in Asia, in Taketoshi Ito and Anne Krueger, eds., The Role of Foreign Direct Investment in Economic Development, Chicago University Press and NBER, Chicago, 9-43.

Belderbos, René A., and Leo Sleuwaegen, 1996, Japanese Firms and the Decision to Invest Abroad: Industrial Groups and Regional Core Networks, Review of Economics and Statistics, 78, 214-220.

Branstetter, Lee, 2000, Vertical Keiretsu and Knowledge Spillovers in Japanese Manufacturing: An Empirical Assessment, Journal of the Japanese and International Economies 14 (2), 73-104.

Bransttetter, Lee, and Robert Feenstra, 1999, Trade and Foreign Direct Investment in China: A Political Economy Approach, NBER Working Paper No. 7100, Cambridge, MA.

Caves, R. E., 1996. Multinational Enterprise and Economic Analysis, second edition. MIT Press, Cambridge, MA.

Cheng, L.K. and Y.K. Kwan, 2000, The Location of Foreign Direct Investment in Chinese Regions: Further Analysis of Labor Quality, in T. Ito and A. O. Krueger (eds.), The Role of Foreign Direct Investment in East Asian Economic Development, Chicago University Press and NBER, Chicago, 213-235.

Coughlin, C.C. and E. Segev, 2000, Foreign Direct Investment in China: A Spatial Econometric Study, World Economy 23, 1-23.

Coughlin, C.C., J.V. Terza and V. Arromdee, 1991, State Characteristics and the Location of Foreign Direct Investment within the United States, Review of Economics and Statistics 73, 675-683.

Devereux, Michael P., and Rachel Griffith, 1999, Taxes and the Location of Production: Evidence from a Panel of US Multinationals, Journal of Public Economics 68, 335-367.

Friedman, J., H.G. Fung, D.A. Gerlowski and J. Silberman, 1996, A Note on "State Characteristics and the Location of Foreign Direct Investment within the United States", Review of Economics and Statistics 78, 367-368.

Fujita, M., 1995, Small and Medium-sized Transnational Corporations: Salient Features, Small Business Economics 7, 251-271.

Ghosal, V. and P. Loungani, 2000, The Differential Impact of Uncertainty on Investment in Small and Large Businesses, Review of Economics and Statistics 82, 338-343. 
Hackett, Steve C., and Krishna Srinivasan, 1998, Do Supplier Switching Costs Differ Across Japanese and US Multinational Firms?, Japan and the World Economy 10, 13-32.

Hausman, J. A. and D. McFadden, 1984, Specification Tests for the Multinomial Logit Model, Econometrica 52, 1377-1398.

Head, K., J. Ries and D. Swenson, 1995, Agglomeration Benefits and Location Choice: Evidence from Japanese Manufacturing Investments in the United States, Journal of International Economics 38, 223-247.

Head, C.K., J.C. Ries and D.L. Swenson, 1999, Attracting Foreign Manufacturing: Investment Promotion and Agglomeration, Regional Science and Urban Economics 29, 197-218.

Head, K. and J. Ries, 1996, Inter-city Competition for Foreign Investment: Static and Dynamic Effects of China's Incentive Areas, Journal of Urban Economics 40, 38-60.

Hines, J., 1996, Altered States: Taxes and the Location of Foreign Direct Investment in America, American Economic Review 86, (5), 1076-1094.

Horiuchi, T, 1989, The Flexibility of Japan's Small and Medium-Sized Firms and Their Foreign Direct Investment, in Kozo Yamamura (ed.) Japanese Investment in the United States: Should We Be Concerned? Society for Japanese Studies, University of Washington, Seattle, Washington.

Krugman, P. R., 1991, Geography and Trade, MIT Press, Cambridge, MA:

Mayer, Thierry and Jean-Louis Muchielli, 1998, Hierarchical Location Choice and Multinational Firm Strategy, paper presented at the Western Economic Association conference at Lake Tahoe, June 28July 2, 1998.

McFadden, G. S., 1984, Econometric Analysis of Qualitative Response Models, in Zvi Griliches and M.D. Intriligator, Handbook of Econometrics, Vol. 2, Elsevier, Amsterdam.

O'Huallachain, Breandan, and Neil Reid, 1997, Acquisition versus Greenfield Investment: The Location and Growth of Japanese Manufacturers in the United States, Regional Studies 31 (4), 403-416.

Reid, Neil, 1994, Just-in-Time Inventory Control and the Economic Integration of Japanese-Owned Manufacturing Plants, Regional Studies 29, 345-355.

Sako, Mari, 1992, Prices, Quality, and Trust: Inter-Firm Relations in Britain and Japan, Cambridge University Press, Cambridge. 
Schmenner, R., J. Huber and R. Cook, 1987, Geographic Differences and the Location of New Manufacturing Facilities, Journal of Urban Economics 21, 83-104.

Shaver, J. Myles and Fredrick Flyer, 2000, Agglomeration economies, firm heterogeneity, and foreign direct investment in the United States, Strategic Management Journal 21, 1175-1193.

Smith, D. and R. Florida, 1994, Agglomeration and Industry Location: An Econometric Analysis of Japanese-affiliated manufacturing establishments in automotive-related industries, Journal of Urban Economics 36, 23-41.

UNCTAD, 1998, Handbook on Foreign Direct Investment by Small and Medium-Sized Enterprises: Lessons from Asia, United Nations, New York..

Venables, A., 1996, Equilibrium Locations of Vertically Linked Industries, International Economic Review 80, 465-479.

Wei, Y., X. Liu, D. Parker and K. Vaidya, 1999, The Regional Distribution of Foreign Direct Investment in China, Regional Studies 33, 857-867.

Wheeler, David, and Ashoka Mody, 1992, International Investment Location Decision, Journal of International Economics 33, 57-76.

Woodward, Douglas P., 1992, Locational Determinants of Japanese Manufacturing Start-ups in The United States, Southern Economic Journal 58, 690-708.

Yamawaki, H., 1992 Location Decisions of Japanese Multinational Firms in European Manufacturing Industries, in: K. Hughes, ed., European Competitiveness, Cambridge University Press, Cambridge. 
Table 1: Summary statistics of dependent and independent variables

\begin{tabular}{|c|c|c|c|}
\hline Name & Description & Mean & Stdev \\
\hline Choice & Binary variabele denoting if region is chosen & 0.0345 & 0.182 \\
\hline Industry agglomeration & Logarithm of number of plants in the electronics industry & 4.509 & 1.463 \\
\hline Japanese agglomeration & Logarithm of number of Japanese electronics plants & 0.735 & 1.148 \\
\hline Keiretsu agglomeration (member) & $\begin{array}{l}\text { Logarithm of number of electronics plants belonging to the } \\
\text { same vertical keiretsu: for member firms }\end{array}$ & 0.0158 & 0.1438 \\
\hline Keiretsu agglomeration (core firm) & $\begin{array}{l}\text { Logarithm of number of electronics plants belonging to the } \\
\text { same vertical keiretsu: for the core firm }\end{array}$ & 0.0218 & 0.1688 \\
\hline GDP & Logarithm of GDP (100 mln Won) & 6.692 & 0.901 \\
\hline Telephone lines per capita & Number of long-distance telephone lines per capita & 5.086 & 5.784 \\
\hline GDP per capita & GDP per capita (10000 Won) & 0.317 & 0.224 \\
\hline Wage level & Average annual wage of staff and workers (1000 Won) & 3.376 & 1.128 \\
\hline Distance to Japan & Distance in flying hours from Japan to region's main airport & 4.731 & 3.104 \\
\hline Seaport & Region has seaport (dummy variable) & 0.379 & 0.485 \\
\hline SEZ-OCC share & $\begin{array}{l}\text { Percentage share of GDP accounted for by cities with } \\
\text { Special Economic Zone or Open Coastal City status }\end{array}$ & 23.562 & 36.711 \\
\hline SME dummy & Parent firm has less than 500 employees (dummy) & 0.319 & 0.466 \\
\hline Local sales ratio & Share of plant output sold on the Chinese market & 0.610 & 0.438 \\
\hline
\end{tabular}

Note: Means and standard deviations are calculated over 29 choices (regions) and 229 choosers (investors), except for the local sales ratio for which data are only available for 193 choosers. Agglomeration counts are increased by one before taking natural logarithms. All time variant variables are measured in period $t-1$. 
Table 2: Conditional logit estimates of plant location choice model (1990-1995)

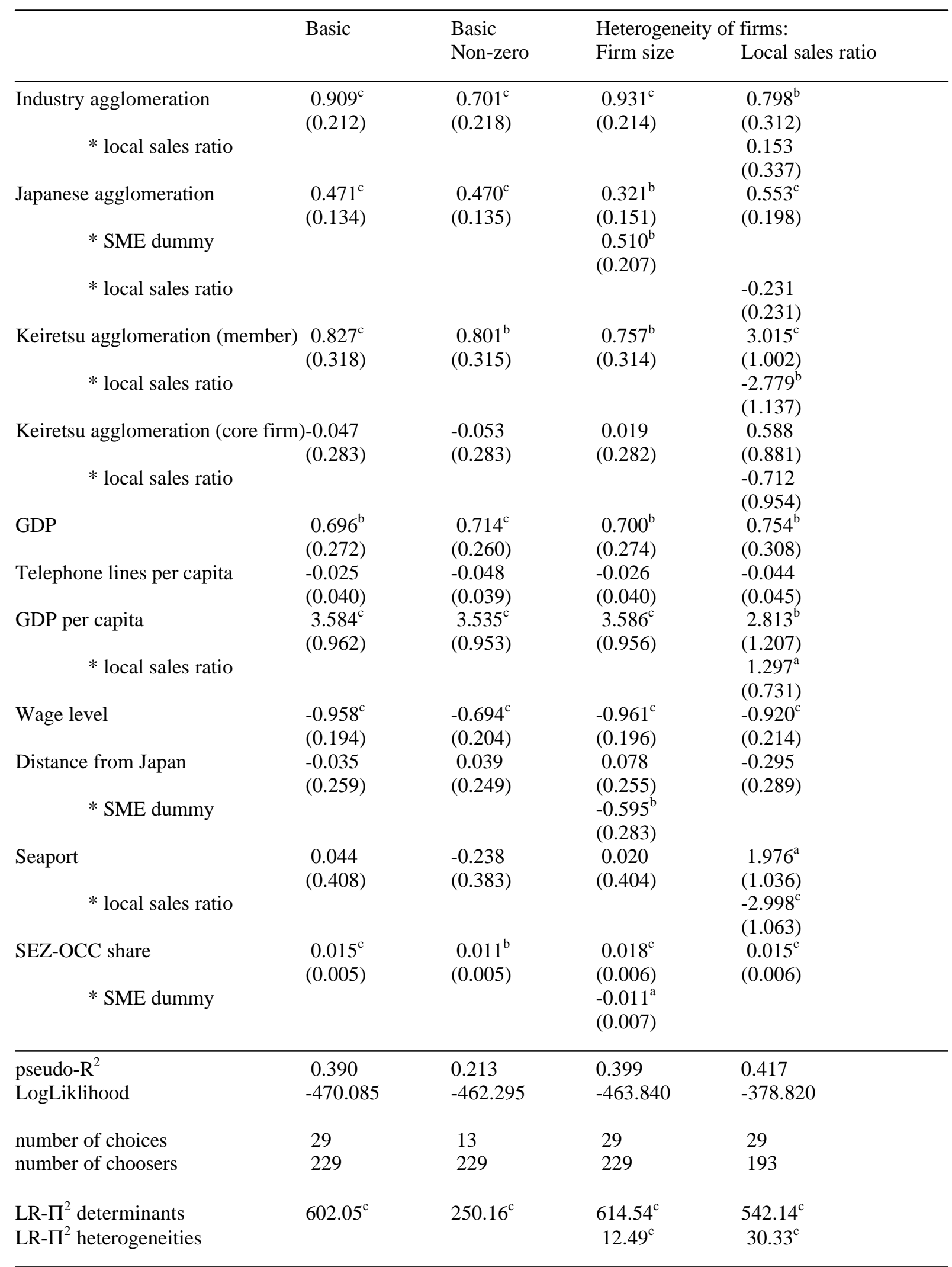

Note: The superscripts $a, b$ and $c$ indicate significance at the $10 \%-, 5 \%$ and $1 \%$-significance level, respectively. The pseudo- $\mathrm{R}^{2}$ is computed as $1-L 1 / L O$, where $L O$ is the constant-only log-likelihood and $L 1$ is the full model log-likelihood. The Hausman-test statistic on IIA concerning the non-zero choice regions is 20.17. The log-likelihood when incorporating both heterogeneity in size and local sales ratio is -374.977 . 


\section{Appendix}

Table A1: Correlation matrix of independent variables in basic model

\begin{tabular}{|c|c|c|c|c|c|c|c|c|c|c|c|}
\hline Variable & 1. & 2. & 3. & 4. & 5. & 6. & 7. & 8. & 9. & 10. & 11. \\
\hline 1. Industry agglomeration & 100 & & & & & & & & & & \\
\hline 2. Japanese agglomeration & 65 & 100 & & & & & & & & & \\
\hline 3. Keiretsu agglomer. (member) & 13 & 21 & 100 & & & & & & & & \\
\hline 4. Keiretsu agglomer. (core firm) & 15 & 26 & -1 & 100 & & & & & & & \\
\hline 5. GDP & 82 & 47 & 10 & 12 & 100 & & & & & & \\
\hline 6. Telephone lines per capita & 41 & 73 & 21 & 25 & 29 & 100 & & & & & \\
\hline 7. GDP per capita & & 43 & 76 & 18 & 22 & 35 & 92 & 100 & & & \\
\hline 8. Wage level & 27 & 60 & 18 & 22 & 34 & 77 & 77 & 100 & & & \\
\hline 9. Distance to Japan & -64 & -34 & -6 & -7 & -60 & -24 & -24 & -4 & 100 & & \\
\hline 10. Seaport & 50 & 56 & 7 & 9 & 38 & 32 & 43 & 29 & -35 & 100 & \\
\hline 11. SEZ-OCC share & 37 & 74 & 16 & 20 & 15 & 70 & 70 & 44 & -30 & 63 & 100 \\
\hline
\end{tabular}




\section{ENDNOTES}

${ }^{1}$ See Coughlin et al. 1991, Friedman et al. 1996, Head et al. 1995, 1999, O'Huallachain and Reid 1997, Schmenner et al. 1987, Smith and Florida 1994, Hines 1996, and Woodward 1992 for investments in the US, Mayer and Muchielli 1998, Yamawaki 1992, Devereux and Griffith 1999 for investments in Europe, and Coughlin and Segev 2000, Cheng and Kwan 2000, Head and Ries 1996, and Wei et al. 1999 for investments in China. Wheeler and Mody (1992) study foreign investment location decisions for a variety of countries.

${ }^{2}$ Shaver and Flyer (2000) proxy for technological and human capital intensity by assuming that these characteristics are correlated by a higher than average size of the establishments in an industry.

${ }^{3}$ See for instance UNCTAD (1998). Inward foreign direct investment as a percentage of gross domestic capital formation reached 26 percent in 1995.

${ }^{4}$ Using Chinese data sources, Head and Ries (1996) had to resort to partial listings of equity joint ventures for both the dependent variable and for the investment agglomeration count. Smaller equity joint ventures and wholly owned firms could not be considered. Cheng and Kwan (2000), Coughlin and Segev (2000) and Wei et al. (1999) do not use plant establishment data but aggregated data on foreign direct investment inflows.

${ }^{5}$ In our sample of Japanese plants in China, slightly more than half of the plants set up by 'core' firms produced final goods; for member firms' plants this percentage was lower but still substantial at 37 percent.

${ }^{6}$ E.g. Horiuchi (1989) reports that the 'core' Japanese automobile manufacturers actively encourage and assisted their keiretsu component suppliers to set up plants near their assembly operations abroad.

${ }^{7}$ This is a variant of the 'dartboard' theory, which suggests including total land area as a measure of the number of potential sites (Coughlin et al. 1991). Land area is not likely to have a major impact on investments in China given the large differences in economic development and land habitation between regions. By including GDP we weigh potential site area with the level of economic development (GDP intensity) of the region. 
${ }^{8}$ We include Beijing as an incentive zone, because the capital of China can offer a range of incentives (Head and Ries 1996). SEZs and OCCs are an only marginally important feature of Guanxi province (OCC Beihai represents 5.6 percent of GDP) and most important (100 percent) in the centrally administered municipalities with OCC status: Shanghai and Tianjin.

${ }^{9}$ Ghosal and Loungani (2000) find evidence that the negative impact of uncertainty on investment is substantially greater in industries dominated by small firms compared with industries dominated by larger firms.

${ }^{10}$ In the 1980s, low levels of local demand and restrictive legislation prevented most foreign affiliates from selling on the local market (see e.g. Head and Ries 1996).

${ }^{11}$ See e.g. Head and Ries (1996) and Head et al. (1999).

${ }^{12}$ Estimation of fixed effects is impossible with the inclusion of time-invariant characteristics such as seaport and SEZ-OCC share and does not allow inclusion of regions that did not attract investment.

${ }^{13}$ The limited influence of adjacent state characteristics may be a corollary of the relatively limited levels of economic integration and trade between China's provinces (Branstetter and Feenstra 1999).

${ }^{14}$ The average elasticity of the probability of locational choice with respect to the agglomeration counts can be calculated as (S-1)/S times the coefficient, where $\mathrm{S}$ is the total number of choices (29). C.f. Head et al. (1995, p. 237).

${ }^{15}$ Telephone lines per capita does have a significantly positive effect once we omit GDP per capita from the model.

${ }^{16}$ To the extent that 100 percent export oriented firms can be assumed not to be influenced by local market potential, the coefficient of the GDP per capita coefficient can also be interpreted as a quality of economic infrastructure effect, and the coefficient of the cross term with the local sales ratio as the pure demand effect.

${ }^{17}$ For instance, Fujita (1995, p. 254) finds that customer and supplier linkages are also judged to be important for foreign direct investment and growth by US and European SMEs active in high technology industries (such as the electronics industry). 